Apidologie, 1986, 17 (3), 193-202

\title{
FORAGING POPULATION SIZES OF AFRICANIZED AND EUROPEAN HONEY BEE (APIS MELLIFERA L.) COLONIES
}

\author{
Robert G. DANKA, Thomas E. RINDERER, Richard L. HELLMICH II \\ and Anita M. COLLINS \\ Honey-Bee Breeding, Genetics and Physiology Laboratory, \\ ARS, USDA, 1157 Ben Hur Rd., Baton Rouge, LA 70820, U.S.A.
}

\begin{abstract}
SUMMARY
Foraging population sizes in Africanized (A) and European (E) honey-bee (Apis mellifera L.) colonies were determined by trapping returning foragers at the hive. $E$ colonies fielded significantly larger foraging populations than A colonies. E colonies showed much larger variability in sizes of foraging populations than A colonies, responding with more foragers as colony size was increased and especially when nectar was more abundant.

The percentage of colony members foraging was similar for both sizes ( 1 and $3 \mathrm{~kg}$ of adult bees) of $\mathbf{E}$ colonies; $1 \mathrm{~kg} \mathrm{~A}$ colonies had a greater percentage of foragers than $3 \mathrm{~kg} \mathrm{~A}$ colonies. E colonies responded with a greater percentage of foragers than $\mathbf{A}$ colonies when nectar was more abundant.
\end{abstract}

\section{INTRODUCTION}

Shifts occur in the size of the foraging force of a honey-bee (Apis mellifera L.) colony according to changing stimuli emanating from both inside and outside the nest. Foraging activity increases with colony size, although the effect of size on the percentage of colony members foraging is unclear (see FrEE and PREECE, 1969). Larger honey-bee colonies have a higher ratio of bees to brood (FARRAR, 1932), thus requiring relatively fewer bees to rear brood. This may allow foraging populations disproportionately greater for larger colonies. Flight activity also increases with greater nectar availability (LUNDIE, 1925 ; SEKIGUCHI et al., 1962). Colonies may increase the proportion of foragers in order to exploit nectar, an ephemeral resource.

We report here work which directly measured foraging population size and the percentage of foraging colony members from Africanized (A) and 
European (E) honey-bee colonies. Colony size and relative nectar availability were other factors examined. The $\mathrm{E}$ stock represented commercially-available bees from North America. These bees evolved in Europe, and are a mixture based mostly on $A . m$. ligustica. The A bees were descendents of bees evolved in tropical Africa (A. m. scutellata), established in South America in 1957, and hybridized to an unknown extent with previously-imported European subspecies.

\section{MATERIALS AND METHODS}

Experimental sessions were conducted in October and December, 1984, near La Miel, Venezuela $\left(09^{\circ} 44^{\prime} \mathrm{N}, 69^{\circ} 08^{\prime} \mathrm{W}\right)$. The area is comprised of tracts of tropical dry forest, secondary grasslands, and small-scale agriculture. The sessions differed principally in the amount of nectar available to foraging bees; nectar was abundant in December, mostly from abundant flowering Hyptis spp. (Lamiaceae). Weather conditions were uniform throughout both sessions, with daily temperature maxima of 30 to $32{ }^{\circ} \mathrm{C}$ and relative humidity ranging from 60 to $90 \%$.

Twelve colonies were established for each experimental session. Three colonies with $3 \mathrm{~kg}$ of bees and three colonies with $1 \mathrm{~kg}$ of bees were used for each honey bee type. The bees came from A colonies started from local feral swarms and $\mathrm{E}$ colonies of stock headed by queens imported from the U.S. Bees were collected from eight or nine colonies of each type and held for about thiee and one-half days in screen cages. They were then hived in two 24-cm depth Langstroth brood chambers below two $17-\mathrm{cm}$ honey supers. Mated queens of the appropriate type were given to each package during holding and later caged in the colonies.

Five frames holding brood of the same type as the adult bees in the colony were placed in the bottom chamber. Each colony was given frames filled with a total of $800 \mathrm{sq} \mathrm{cm}$ of unsealed brood and $1200 \mathrm{sq} \mathrm{cm}$ of sealed brood. The quantities of brood used were small (equivalent to about one full frame of brood) to enable the $1 \mathrm{~kg}$ units to effectivelly care for the immature bees. Two frames with honey and two with pollen and honey were placed next to the brood frames; supers contained frames of empty, drawn comb.

The foraging population in each colony was estimated by trapping all bees returning to the hive from the field. A forager trap was mounted on the front entrance of the hive when the colonies were established. All bees entering and leaving the hive passed through the trap via access tubes; the diameter of the tubes permitted bees to crawl through them, but not fly through them. To trap bees, the interiors of the access tubes were coated with paraffin oil and a bag was placed inside the trap body. Returning bees entered the tubes as usual, but then slipped, fell into the bag, and were unable to crawl back out of the trap through the oiled tubes. Caught foragers were either counted or their number was calculated by weighing the total catch and a sample from the bag. Bees were released from the traps after counting. Details of the trap and procedure (unpub. data) are available from the authors' laboratory.

Bees were trapped on three consecutive mornings in each trial beginning one week after colony establishment. Trapping occurred during peak morning flight times for the colonies (0800 to 0900 hours, local time). Relative foraging by the two bee types at this time is typical of patterns during most of the day (unpub. obs.).

It is likely that not all bees returning to the colonies were foragers; some probably were on orientation or cleansing flights. The number of such bees was assumed to be negligible and proportionately similar for the two ecotypes. Also, some members of the foraging population were in the hives between trips when trapping took place. This proportion of foragers was also assumed equal 
for both bee types. However, there is evidence that $\mathrm{A}$ foragers spend slightly less time in their hives than E foragers (about $3.1 \mathrm{~min} / \mathrm{h}$; WINSTON and KATZ, 1982). This would tend to inflate estimates of Africanized foragers.

Fifty-bee samples collected from the holding cages during each experimental session had average weights of $116 \pm 12 \mathrm{mg}(\overline{\mathrm{x}} \pm \mathrm{SE})$ for the $\mathrm{E}$ bees and $104 \pm 11 \mathrm{mg}$ for the $\mathrm{A}$ bees. Therefore, $\mathbb{E}$ colonies had about 8,700 bees per $\mathrm{kg}$ and $\mathrm{A}$ colonies had about 9,700 bees per $\mathrm{kg}$. These population estimates were used to calculate the percentage of colony members which were foraging during trapping. Mortality in the colonies probably caused underestimation of the percentages of bees foraging.

Analysis of variance was performed on rank transformations (SIEGEL, 1956) of numbers of foragers per colony and their associated percentages; data were transformed due to heterogeneity of variances. In the model, colony size and nectar availability factors were nested within the main effect (bee type). Observations from two of the 24 colonies were omitted because of worker population loss, as assessed at the end of the trapping period. Sample sizes were 11 for the main effect means, 6 or 5 for two-way interactions, and 3 or 2 for three-way interactions.

\section{RESULTS}

Overall, E colonies had more foragers per colony $(\overline{\mathrm{x}}=720)$ than A colonies $\overline{\mathrm{x}}=240$ ) (Table 1, «Bee type $»)$. E colonies exhibited much greater fluctuations in size of foraging populations (42 to 1679 foragers per colony) than A colonies (119 to 352 foragers per colony) (Table 2). Within the $\mathrm{E}$ bees, colony size and nectar availability factors were each significant. There were 2.8 times as many foragers in larger colonies and 6.6 times as many foragers when nectar was more abundant. Within the A bees, colonies had similar numbers of foragers for each colony size and each period of nectar availability. However, a significant interaction between these factors was evident (Table 1); the number of foragers in $3 \mathrm{~kg}$ A colonies increased 3.0 times with an increase in nectar availability, while $1 \mathrm{~kg} \mathrm{~A}$ colonies had slightly fewer foragers during the period with more nectar.

TABL. 1. - Results of analyses of variance on the ranks of number of foragers per colony and the percentage of colony members foraging

\begin{tabular}{|c|c|c|c|c|c|}
\hline \multirow{2}{*}{ Effect } & \multirow{2}{*}{ df } & \multicolumn{2}{|c|}{$\begin{array}{c}\text { Number of foragers } \\
\text { per colony }\end{array}$} & \multicolumn{2}{|c|}{$\begin{array}{c}\text { Percentage of colony } \\
\text { members foraging }\end{array}$} \\
\hline & & MS & Prob F & MS & Prob F \\
\hline Bee type & 1 & 85.33 & 0.02 & 75.00 & 0.02 \\
\hline Within Africanized: & & & & & \\
\hline Colony size & 1 & 0.91 & 0.78 & 88.17 & 0.01 \\
\hline Nectar availability & 1 & 8.17 & 0.43 & 2.24 & 0.66 \\
\hline Colony size $*$ nectar availability & 1 & 56.02 & 0.05 & 88.17 & 0.01 \\
\hline Within European : & & & & & \\
\hline Colony size & 1 & 109.80 & 0.01 & 11.57 & 0.33 \\
\hline Nectar availability & 1 & 378.69 & 0.01 & 422.24 & 0.01 \\
\hline Colony size * nectar availability & 1 & 40.91 & 0.09 & 56.02 & 0.04 \\
\hline Error & 14 & 11.98 & & 11.21 & \\
\hline
\end{tabular}




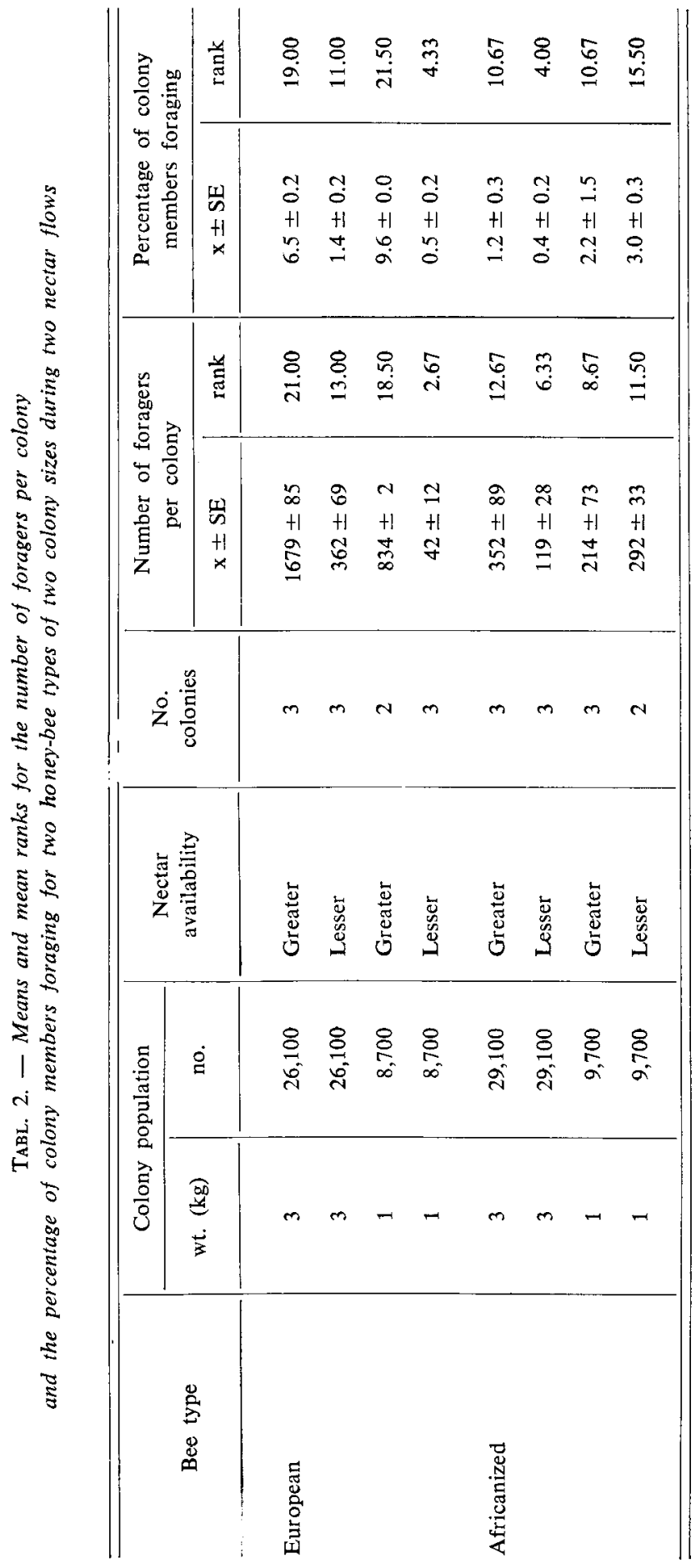


Overall, the percentage of colony members foraging was higher for $\mathrm{E}$ colonies $(\overline{\mathrm{x}}=4.0 \%$ ) than $\mathrm{A}$ colonies $(\overline{\mathrm{x}}=1.6 \%$ ) (Table 1 , «Bee type $\gg)$. E colonies of both sizes had similar percentages of bees foraging. The percentage of $E$ bees foraging was 8.1 times as great when more nectar was available, reaching a maximum of $9.6 \%$ in $1 \mathrm{~kg}$ colonies. The increase in the percentage of $\mathrm{E}$ bees foraging when nectar was more abundant was relatively greater in $1 \mathrm{~kg}$ colonies than in $3 \mathrm{~kg}$ colonies. For the $\mathrm{A}$ bees, the percentage of colony members foraging was 3.2 times greater in $1 \mathrm{~kg}$ colonies than in $3 \mathrm{~kg}$ colonies. A maximum of $3.0 \%$ of $\mathrm{A}$ bees foraged; this occurred in $1 \mathrm{~kg}$ colonies during the period of lesser nectar availability. The percentage of foragers was similar in each period of nectar availability. The percentage of bees foraging in $3 \mathrm{~kg} \mathrm{~A}$ colonies increased 3.0 times with an increase in nectar availability, while $1 \mathrm{~kg} \mathrm{~A}$ colonies had a lower percentage of foragers during the period with more nectar.

At the colony level, variability relative to the mean was much greater among A colonies than among $E$ colonies for both of the variables measured. For $A$ colonies, the coefficients of variation $(s / \overline{\mathrm{x}} \times 100)$ were $47 \%$ for the numbers of foragers per colony and $43 \%$ for the percentage of colony members foraging; for $\mathrm{E}$ colonies, they were $14 \%$ and $17 \%$, respectively.

\section{DISCUSSION}

Sizes of foraging populations in $\mathrm{E}$ honey-bee colonies varied greatly depending on colony size and especially according to nectar availability; A colonies were only minimally influenced by these factors. E colonies appear to be better able to regulate their foraging populations toward exploiting strong nectar flows. The response difference between the two bee types is most likely due to their contrasting evolutionary ecologies. $\mathrm{E}$ bees evolved in temperate ecosystems, which characteristically are more predictably heterogeneous in seasonal nectar presentation than tropical environments (BAWA, 1983). Thus, E bees regularly have been exposed to periods with abundant nectar interspersed among times of dearth. Selection pressures would favor bees maximizing nectar collection when the resource was available. Artificial selection for increased honey production, historically practiced much more with European than with African subspecies, also enhances nectarcollecting abilities. Individual $\mathrm{E}$ foragers and $\mathrm{E}$ colonies have other traits which lead to superior nectar harvesting under good nectar flow conditions (RINDERER et al., 1984, 1985 ; Pesante et al., 1985).

Several life history characteristics may predispose A colonies to fielding typically smaller foraging populations. Relatively greater quantities of brood in A nests (unpublished data) probably require larger nurse-bee populations for 
care, resulting in fewer foragers. Intense colony defense by A colonies (Collins et al., 1982) also may translate to fewer bees foraging. A large amount of artificial manipulation was required to establish the homogeneous units used in our study. After such manipulation, A colonies may not regain social homeostasis as quickly as E colonies; this could affect foraging performance. Testing this hypothesis may help predict $\mathrm{A}$ bee responses to the intense management often associated with commercial honey production and crop pollination in North America. The high variability of response by the A colonies suggests that improvement of foraging-related traits may be made through selection programs.

The percentage of $\mathrm{E}$ bees foraging remained constant as colony size was varied; this finding agrees with the conclusions of some earlier workers (FARRAR, 1931 ; Woodrow, 1934 ; Gooderham, 1950 ; SeKiguchi et al., 1962). A higher ratio of bees to brood is normally found in larger colonies; this trend was mimicked here, but did not appear to influence the proportion of bees foraging. The presence of brood prompts foraging in honey bee colonies (FrEE, 1967); perhaps the small amount of brood supplied to the $3 \mathrm{~kg}$ units did not stimulate them to forage maximally. The $4.1 \%$ of $\mathrm{E}$ bees found to forage per colony is nearly identical to the $4.3 \%$ found by JAYCOX (1970) in small E colonies. Free and PreEce (1969) found that large colonies of temperately-evolved honey bees decrease foraging activity relatively more than smaller-sized units as foraging conditions worsen. Our limited study indicated that A colonies followed this trend, while E colonies showed an opposite tendency.

Response differences between the bee types were large enough to be revealed with relatively small numbers of colonies. Repeated measures with more colonies could detect smaller differences. Further research in more varied conditions is necessary to permit broader inferences concerning the dynamics of foraging population of $\mathrm{E}$ and $\mathrm{A}$ bees. Knowledge of both the size of the foraging population and the efficiencies of individual foragers as pollinators is critical in evaluating the worth of a colony as a pollinating unit. Further studies are essential for assessing the probable impact of Africanized bees on agroecosystem pollination in North America.

\section{ACKNOWLEDGEMENT}

We thank R. Colmenares, A. Escalona, J. Jennings, V. Lancaster, and R. Spencer for assistance in the field. V. WRIGHT and D. BOYKIN made suggestions concerning statistical analyses. In cooperation with the Louisiana Agricultural Experiment Station and Universidad de Centro Occidental Lisandro Alvarado, Barquisimeto, Venezuela.

Received for publication in January 1986. Accepted for publication in May 1986. 


\section{RESUME \\ TAILLE DES POPULATIONS DE BUTINEUSES \\ DANS LES COLONIES D'ABEILLES AFRICANISEES ET EUROPEENNES}

On a réalisé 2 expériences d'une semaine chacune, dans lesquelles la quantité de nectar disponible pour les butineuses variait. Six colonies d'abeilles africanisées (A) et six d'abeilles européennes (E) ont été constituées pour chaque expérience; sur les six, trois avaient $3 \mathrm{~kg}$ d'abeilles, les 3 autres $1 \mathrm{~kg}$ d'abeilles. Les abeilles A provenaient de colonies issues d'essaims sauvages; les abeilles E étaient produites par des reines des Etats-Unis. Toutes les colonies ont été installées dans des ruches Langstroth de 2 boîtes de $24 \mathrm{~cm}$ et 2 de $17 \mathrm{~cm}$ de profondeur. Chaque ruche a été pourvue de cadres avec environ $800 \mathrm{~cm}^{2}$ de couvain non operculé, de $1200 \mathrm{~cm}^{2}$ de couvain operculé, du miel et du pollen en quantité suffisante.

Une semaine après la constitution des colonies, les abeilles qui rentraient à la colonie étaient capturées le matin pendant 3 jours consécutifs. Les pièges utilisés pour capturer les abeilles étaient des boîtes fixées sur le devant des ruches au-dessus de l'entrée. Chaque couvercle de piège comportait des trous ajustés à des morceaux de tube en plastique dans lesquels les abeilles pouvaient ramper, mais non voler. Pour capturer les abeilles, l'intérieur des tubes était enduit à l'huile de paraffine et un sac était attaché à la partie inférieure du couvercle. Les abeilles qui rentraient à la ruche tombaient dans les sacs et étaient incapables de ressortir en rampant. Le nombre d'abeilles capturées a été calculé d'après le poids; le pourcentage des membres de la colonie capturés a été évalué d'après le nombre de captures et le nombre moyen d'abeilles par $\mathrm{kg}$ dans les colonies.

Dans l'ensemble les colonies $\mathrm{E}$ ont réuni des populations de butineuses significativement plus grandes que les colonies $\mathbf{A}$ (Tabl. 1 et 2 ). Ces colonies $\mathbf{E}$ ont réagi beaucoup plus que les colonies $\mathbf{A}$, par la taille de la population de butineuses, à l'accroissement de la taille de la colonie et de la disponibilité en nectar. On a aussi évalué le pourcentage des membres d'une colonie qui butinaient. Le pourcentage des butineuses a été semblable pour les 2 tailles des colonies E (1 et $3 \mathrm{~kg}$ d'abeilles), tandis que des colonies $\mathrm{A}$ d' $1 \mathrm{~kg}$ ont eu un pourcentage de butineuses supérieur à celui des colonies A de $3 \mathrm{~kg}$. Au total les colonies $\mathbf{E}$ ont eu des pourcentages plus élevés de butineuses et de plus grandes variations dans le pourcentage des butineuses, quand les facteurs du milieu variaient.

La plus forte réaction des colonies $\mathrm{E}$ à une disponibilité accrue en nectar est vraisemblablement due à leur évolution dans des écosystèmes caractérisés par l'hétérogénéité de la disponibilité en nectar ; ces abeilles semblent être équipées pour maximiser la récolte du nectar lors de fortes miellées. Réciproquement, les abeilles $\mathrm{A}$, qui ont un passé évolutionnaire dans des régions tropicales (où la disponibilité en nectar est plus uniforme), semblent moins capables de réagir par un nombre accru de butineuses à de fortes miellées. Les colonies A sont peut-être prédisposées pour réunir des quantités relativement faibles de butineuses en raison de l'élevage extensif de couvain, de la défense vigoureuse de Ia colonie et de l'éclatement social provoqué par les manipulations.

\section{ZUSAMMENFASSUNG}

\section{GRÖSSE DER SAMMLERSCHAR AFRIKANISIERTER UND EUROPAISCHER BIENENVÖLKER}

Es wurden zwei Versuche von je einer Woche Dauer durchgefübrt, die sich in dem Nektarangebot für die Sammelbienen unterschieden. Für jeden Versuch wurden je sechs Völker von afrikanisierten (A) und europäischen (E) Bienen gebildet, und zwar drei Völker aus $3 \mathrm{~kg}$ Bienen und drei aus einem $\mathrm{kg}$ Bienen. Die A-Bienen stammten aus wilden Schwärmen, die E-Bienen wurden 
Völkern mit Königinnen aus den U.S.A. entnommen. Es wurden von mindestens acht Völkern jedes Bienentyps Bienen gesammelt. Alle Völker befanden sich in Langstroth-Kästen mit zwei Zargen zu $24 \mathrm{~cm}$ Tiefe und zwei zu $17 \mathrm{~cm}$ Tiefe. Jedes Volk erhielt Waben mit etwa $800 \mathrm{~cm}^{2}$ offener und $1200 \mathrm{~cm}^{2}$ verdeckelter Brut, und genügend Honig und Pollen zum Überleben.

Beginnend etwa eine Woche nach Bildung der Völker wurden an drei aufeinanderfolgenden Morgen heimkehrende Flugbienen abgefangen. Als Fallen, die zum Abfangen der Bienen benutzt wurden, dienten Kästchen, die oberhalb des Fluglochs fest an der Vorderseite der Beute befestigt waren. Die Deckel der Kästchen hatten Löcher mit eingesetzten Stücken eines Plastikschlauches, durch den die Bienen kriechen, aber nicht fliegen konnten. Zum Abfangen der Bienen wurde die Innenseite des Schlauches mit Paraffin beschichtet und an der Unterseite des Deckels ein Sack aus Gittergewebe angebracht. Heimkehrende Bienen fielen in den Sack und sie waren nicht in der Lage, wieder herauszukriechen. Die Anzahl gefangener Bienen wurde durch Wägen bestimmt; der perzentuelle Anteil der gefangenen Bienen an der Gesamtzahl des Volkes wurde aus der Zahl gefangener Bienen und aus der Bienenzahl im Volk (je $\mathrm{kg}$ ) berechnet.

Insgesamt sandten E-Völker signifikant mehr Trachtbienen aus als A-Völker (Tab. 1 und 2). E-Völker zeigten eine viel stärkere Reaktion in Hinsicht auf die Größe der Sammelschar als A-Völker, sobald die Volksstärke und besonders sobald das Nektarangebot erhöht wurden. Es wurde such der Prozentsatz der Sammelbienen an der Gesamtbienenzahl des Volkes berechnet. Der Prozentsatz der Trachtbienen war bei den E-Völkern für beide Volksstärken gleich; aber A-Völker zu einem $\mathrm{kg}$ hatten einen größeren Prozentsatz an Trachtbienen als die Drei-kg-Völker. E-Völker wiesen einen größeren Gesamtprozentsatz an Trachtbienen auf und sie zeigten eine größere Variabilität des Anteils der Trachtbienen, wenn sich die Umweltbedingungen änderten.

Die stärkere Reaktion der E-Völker auf ein erhöhtes Nektarangebot ist höchstwahrscheinlich auf ihre Evolution in einem Ökosystem mit großen Trachtschwankungen zurückzuführen. Diese Bienen scheinen dazu veranlagt zu sein, aus einer starken Tracht den höchstmöglichen Ertrag einzubringen. Im Gegensatz dazu scheinen A-Bienen, die aus einem tropischen Gebiet mit mehr gleichförmigem Trachtangebot stammen, weniger gut befähigt zu sein, ein gutes Trachtangebot mit einer größeren Anzahl von Sammlerinnen zu beantworten. A-Völker könnten prädisponiert sein, wegen der starken Bruttätigkeit, der heftigen Volksverteidigung und wegen der Störungen infolge der Eingriffe in das Volk eine relativ kleinere Schar von Trachtbienen auszusenden.

\section{BIBLIOGRAPHY}

BAWA K.S., 1983. - Patterns of Flowering in Tropical Plants. In : Handbook of Experimental Pollination Biology, C.E. Jones and R.J. Little, eds. van Nostrand Reinhold, Inc., New York.

Collins A.M., Rinderer T.E., Harbo J.R., Bolten A.B., 1982. - Colony defense by Africanized and European honey bees. Science, 218, 72-74.

Farrar C.L., 1931. - The evaluation of bees for pollination. J. Econ. Entomol., 24, 622-627.

FaRRAR C.L., 1932. - The influence of the colony's strength on brood-rearing. 51st and 52nd Annual Report of the Beekeepers' Association of the Province of Ontario, 1930 and 1931 (Ontario Dept. Agric.), 126-130.

FreE J.B., 1967. - Factors determining the collection of pollen by honeybee colonies. Anim. Behav., 15, 134-144.

Free J.B., Preece D.A., 1969. - The effect of the size of a honeybee colony on its foraging activity. Insectes Soc., 16, 73-78.

Gooderham C.B., 1950. - Overwintered colonies versus package bees for orchard pollination. Prog. Rep. Dom. Apiarist Canad. Dept. Agric., 1937-1948 (publ. 1950), 7-8. 
JAYCOX E.R., 1970. - Honey bee queen pheromones and worker foraging behavior. Ann. Ent. Soc. Am., 63, 222-228.

Lundie A.E., 1925. - The flight activities of the honeybee. U.S. Dept. Agric. Bull., No. 1328.

Pesante D., Rinderer T.E., Colins A.M., 1985. - Differential nectar foraging by Africanized and European honeybees in the neotropics. (Submitted).

Rinderer T.E., Bolten A.B., Collins A.M., Harbo J.R., 1984. - Nectar-foraging characteristics of Africanized and European honeybees in the neotropics. J. Apic. Res., 23, 70-79.

Rinderer T.E., Collins A.M., Tucker K.W., 1985. - Honey production and underlying nectar harvesting activities of Africanized and European honeybees. J. Apic. Res., 23, 161-167.

Sekiguchi K., Ueda M., SAKagami S.F., 1962. - Daily change of foraging populations in same-aged groups of honeybee workers (Preliminary report). Jap. J. Zootech. Sci., 33, 208-213.

Siegel S., 1956. - Nonparametric statistics for the behavioral sciences. McGraw-Hill, New York.

Winston M.L., Katz S.J., 1982. — Foraging differences between cross-fostered honeybees workers (Apis mellifera) of European and Africanized races. Behav. Ecol. Sociobiol., 10, 125-129.

Woodrow A.W., 1934. - The effect of colony size on the flight rates of honey-bees during the perıod of fruit blossom. J. Econ. Entomol., 27, 624-629. 